\title{
Sorbán Angella*
}

\section{POSZTMODERN CSELÉDSORS?"* HÁZTARTÁSI ÉS GONDOZÓI MUNKÁT VÉGZŐ ERDÉLYI NŐK KÜLFÖLDÖN}

Kulcsszavak: női vendégmunka, transznacionális migráció, házimunka, gondozói munka, 21. század eleji társadalomszerkezeti változások

\section{BEVEZETÉS}

Az ENSZ adatai szerint az elmúlt fél évszázadban a nemzetközi migránsok száma megkétszereződött (körülbelül 190 millió ember nem abban az országban él, ahol született), és ennek felét nók alkotják. ${ }^{1} \mathrm{~A}$ nemzetközi összehasonlító vizsgálatok ugyanakkor a migráció további elnőiesedésére hívják fel a figyelmet, ${ }^{2}$ sajátos kérdésekkel szembesítve a kutatókat: milyen gazdasági-társadalmi okok generálják a nők vándorlásának eltömegesedését? Miben különböznek a női migráció jellemzői (hálózatok, típusok stb.) a férfiakétól? Milyen következményekkel jár a külföldi munka a női szerepértelmezésekre, családmodellekre a világ különféle térségeiben? Melyek tehát a legfőbb okai, és melyek a kísérőjelenségei a nők ilyen méretű vándorlásának a 21. század elején?

Tekintettel arra, hogy a migráns nők túlnyomó része az ún. harmadik világból, a volt gyarmatokról, utóbbi évtizedekben pedig egyre növekvő számban a posztszocialista térségből érkezik a fejlett országokba, az okokra vonatkozólag kézenfekvő magyarázatnak tűnik, hogy a nők tömegessé vált nemzetközi migrációjának fó mozgatója az otthoni szegénység enyhítése, illetve nyugatias(abb) életszínvonal biztosítása az otthon maradt családtagoknak, hozzátartozóknak. Különösebb kutatások nélkül is megállapítható, hogy emögött - mint (el)indulási motiváció - messze elmarad a női karrierépítés, s közismert az is, hogy a jelenség összefügg a fejlett országokban kialakult kereslettel sajátosan a női munka iránt (háztartási munka, gyer-

* Sorbán Angella, PhD (1965), szociológus, a Sapientia EMTE Kutatási Osztályának vezetője. E-mail: sorbanangella@yahoo.com, sorbanangella@sapientia.ro.

** A kutatás, amelyre a tanulmány épül, az MTA Domus Szülőföldi Ösztöndíjprogram támogatásával készült 2013-2014-ben.

1 Andrew R. Morrison et al.: The Internation Migration of Women. Palgrave Macmillan, New York, 2008.

2 Elisabeth M. Grieco-Monica BoyD: Women and Migration: Incorporating gender into international migration theory. Center for the Study of Population, Florida State University, W.P, 1998; Jan RYAN: Globalization and Migration in the 21st Century: Looking Back into the Future. Forum on Public Policy. A Journal of the Oxford Round Table 2007. Spring. 1-19; Hania Zlotik: The Golbal Dimensions ofFemale Migration.Migration Information Surse 2003.http://www.migrationformation. org (letöltés dátuma: 2013. május). 
mekfelügyelet, idősgondozás stb.), ami a maga során a fejlett országokban bekövetkezett demográfiai és társadalomszerkezeti átalakulásokkal jár együtt.

Ez a kontextuális háttér fő vonalaiban éppen magyarázná is a női migráció eltömegesedését, ám minden bizonnyal ennél jóval összetettebb gazdasági és társadalmi jelenséggel állunk szemben; a folyamat jellemzőinek és következmények feltárása - akár a női sorsokra és szerepekre, akár az érintett országok társadalmi berendezkedésére - az elkövetkezendő évtizedekben további gender-érzékeny vizsgálatok sorát teszi szükségessé.

Noha nem áll rendelkezésre megbízható kimutatás arról, hogy a szegényebb országból érkező nők milyen arányban dolgoznak legálisan vagy feketén, sem pedig arról, hogy a globális munkaerôpiacon százalékos megoszlásban milyen konkrét foglalkozásokban vannak alkalmazva, annyi a szakirodalom szelektív áttekintése alapján is megbecsülhető, ${ }^{3}$ hogy többségük alacsony státusú állásokban, illetve háztartási alkalmazottként dolgozik külföldön, s a munkapiac láthatatlan felén tömegével látnak el gyermekfelügyeletet, valamint idősgondozói feladatokat nyugati családoknál.

2011-2012-ben a Migráció és gazdasági kultúra c., Erdélyben lefolytatott vizsgálatunk ${ }^{4}$ során hasonló tendenciákat tapasztaltunk: a mintába bekerült erdélyi nők túlnyomó többsége ugyanis takarítónő, bejárónő, ún. bébiszitter vagy idősgondozó volt külföldön, függetlenül iskolai végzettségétől vagy itthon gyakorolt foglalkozásától, és ez irányította a figyelmet - erdélyi perspektívából is - erre a fajta női vendégmunkára.

Jelen tanulmány ennek a kutatásnak az eredményeire épít, amelyet 2013-2014-ben egy újabb vizsgálat követett, ezúttal kizárólag a nói vendégmunkára és ezen belül is a háztartási, illetve a gondozói munkára fókuszálva. ${ }^{5}$ A 2011-2012-es kutatás során 11 nő került a mintába (románok és magyarok vegyesen), ebből 8-an háztartási és/vagy gondozói munkát (is) végeztek külföldön (átlagéletkor 36,1 év). A 2013-2014-es vizsgálat során 9 nővel készült mélyinterjú (átlagéletkor 48,6 év), amelyet be nem avatkozó megfigyeléssel egészítettünk ki. ${ }^{6}$ Bár a szóban forgó vizsgálatok kvalitatív jellegük folytán nem követtek reprezentativitási szempontokat - az interjúalanyok hólabdamódszerrel kerültek a mintába -, az átlagéletkor mindkét kutatás esetében arra figyelmeztet, hogy a külföldi munkavállalás a nőknél életkor tekintetében meglehetősen kitolódik, sőt, elég gyakori, hogy a nyugdíjas kor körüli/utáni időszakra tevődik. Utóbbi esetben a középkorú vagy idősebb nők főként idősgondozást vállalnak külföldön, mely folyamat igen sajátos aspektusait körvonalazza a nők nemzetközi vándorlásának, értve ez alatt ennek a munkának a jellemzőit, az idősgondozást végző nők migrációs hálózatait, illetve önképének és szerepértelmezéseinek változásait.

3 A vonatkozó, rendkívül gazdag szakirodalom teljes áttekintésére nem vállalkozhatunk. Néhány fontosabb munkára történik utalás a tanulmányban.

4 A hivatkozott kutatás ugyancsak az MTA Domus Szülőföldi Ösztöndíjprogram támogatásával készült. Központi kérdése az volt: milyen az erdélyiek nézőpontjából a munka világa külföldön, hogyan írhatók le a vándorlás során kikristályosodó (érték)választások és (gazdasági) gondolkodásmódok a 21. század fordulóján. A kutatás eredményeiből önálló könyv készült: Óh a Nyugat, a Nyugat! Migráció és gazdasági kultúra címmel, amelyben külön fejezet foglalkozik az Erdélyből nyugatra tartó női vendégmunka sajátosságaival.

5 A részletes módszertani összefoglalást lásd a mellékletben.

6 Családi látogatások, illetve két utazás menetrend szerinti járatokkal Székelyudvarhely-Budapest és Kolozsvár-Budapest útvonalon. 


\section{AZ EGYENLŐTLENSÉGEK ÉS A GONDOSKODÁS NEMZETKÖZI LÁNCOLATA}

Bartha Eszter Visszatérnek a háztartási alkalmazottak? Paradigmák a fizetett házimunkáról c. tanulmányában ${ }^{7}$ abból indul ki, hogy a történelem nem igazolta azt a szociológusi jóslatot, miszerint a háztartási munka, mint fizetett foglalkozás, a modernizáció (s ezzel együtt a háztartási gépek elterjedése) hatására eltűnik, sőt, a posztindusztriális korban növekvő igény mutatkozik iránta, ezért az effajta női munkát, különösen a nemzetközi munkaerő-vándorlás kontextusában, más értelmezési keretbe szükséges helyezni.

A jelenség magyarázatára egyik lehetséges közelítésmódnak a szegmentált munkaerőpiac elmélete kínálkozik. Eszerint a külföldről (a szegény országokból) érkező nők tömegei előtt - belépőként - nyitott az út az ilyen (az otthonihoz képest „fizetett”, sőt magas jövedelmet ígérô) foglalkozásokhoz, az azonban már kérdéses, hogy az érintett nők számára ez inkább átmenetet jelent-e magasabb presztízsű foglalkozásokhoz, vagy eleve kijelöli a külföldi nők fő mozgásterét a nemzetközi munkapiacon, önjáróvá téve ezt a szegregációt.

Másik értelmezési keret Bartha szerint az ún. „rendszerkritikus feminista nézőpont”. Ez a meglehetősen radikális elemzési perspektíva a globális kapitalista gazdaság, a gazdasági, hatalmi, nemi, etnikai egyenlőtlenségek összefüggésrendszerébe helyezi a női munkaerő-vándorlás jelenségeit, alapvetően Enloe, ${ }^{8}$ Anderson, ${ }^{9}$ valamint Parreñas ${ }^{10}$ munkáira alapozva. A szóban forgó megközelítés szerint a házimunkások migrációját a nemzetközi adósságpolitika, kiemelten pedig a Nemzetközi Valutaalap tevékenységének globális kontextusában szükséges szemlélni, abból kiindulva, hogy a nők tömeges méretű külföldi munkavállalását végeredményben az IMF által, az országok számára előírt megszorító politika (a szociális támogatások csökkentése, az egészségügy és az oktatás privatizációja, a drágulások, egyidejüleg a fizetések és a nyugdíjak alacsony szinten tartásával) generálja. A megszorító intézkedések ugyanis jelentősen megnövelik a háztartások terheit, amelyekkel a nők - akikre ezek a terhek hagyományosan nehezednek - csak úgy tudnak megbirkózni, hogy külföldön vállalnak munkát, így végeredményben saját országuk „nemzetközi adósságpolitikáját menedzselik azáltal, hogy fürdőszobákat takarítanak a bankárok országában”. ${ }^{11}$

Tolstokorova ukrán kutató ugyanakkor a tömeges női migráció következményeire hívja fel a figyelmet. ${ }^{12}$ Úgy véli a női munkaerő-vándorlás egyenlege a kibocsátó közösségek szempontjából veszteséges, tekintve, hogy a helyi közösségek szétszabdalásához (social surgery), a

7 Bartha Eszter: Visszatérnek a háztartási alkalmazottak? Paradigmák a fizetett házimunkáról. Szociológiai Szemle 19(2009). 4 sz. 68-86.

8 Cynthia Enloe: Bananas, Beaches and Bases. Pandora, London, 1989.

9 Bridget J. Anderson: Doing the Dirty Work? Global politics of Domestic Labour. Zed Books, London, 2007.

10 Rhacel S. Parreñas: Migrant Fillipina Domestic Workers and the International Division of Reproductive Labour. Gender\&Society 14(2000). 14 sz. 560-580; Uó: Servants of Globalization. Women, Migration and Domestic Work. Stanford University Press, 2003.

11 BARTHA: $i . m .78$.

12 Alissa Tolstokorova: Of Women's Bondage: Socio-Economic Effects of Labour Migration on the Situation of Ukrainian Women and Family. Acta Univeritatis Sapientiae. Social Analysis 2(2012). 2 sz. 9-29. 
családi értékek devalválódásához, elidegenedéshez, az emberi, családi kapcsolatok elüzletiesedéséhez, az erőszak és a deviancia térnyeréséhez vezet, az otthon maradt gyermekek nevelésével együtt járó problémákról nem is beszélve - miközben az ilyen áron realizált anyagi felhalmozás értéke viszonylagos. S bár a nők külföldi munkavállalása - neoliberális értelmezésben - az anyagi önállóság, az emancipáció ígéretét hordozza magában, a tapasztalat azt mutatja, hogy gyakori, hogy ennek éppen az ellenkezője történik. Tehát a külföldi munka nem hogy nem változtat az érintett nők helyzetén, hanem terheiket, kiszolgáltatottságukat még inkább megnövelheti, abból kifolyólag, hogy ezáltal még inkább belebonyolódhatnak a különféle családi kötelékek, függőségek, elvárások, akár zsarolások szövevényébe. ${ }^{13}$

A női migráció vázolt kritikai perspektívája ráirányítja a figyelmet egyrészt ennek a fajta munkának a pszichológiai vonzataira, másrészt pedig a gondoskodás nemzetközi transzferére. $^{14}$

A házi- és gondozói munka jellege miatt elég nehezen körülhatárolható, ami jórészt abból adódik, hogy egy idegen családba/háztartásba bekerült ún. ,alkalmazott” pszichológiai/érzelmi apportja fontos összetevője a mindennapi munkavégzésnek. Informális alku tárgya, hogy mi is tartozik valójában az elvégzendő feladatok körébe, mettől meddig tart a munkaidő, mit ad hozzá a munka minőségéhez az odaadás, az önzetlenség, a lojalitás, a megbízhatóság vagy egy-egy felmerülő ügy/probléma sajátként való megélése, kezelése? Ezek a „munkaadó” részéről jobbára magától értetődő elvárások, az „alkalmazottnak” viszont különleges pszichológiai és morális megterhelést, sőt kiszolgáltatottságot jelenthetnek. Olyannyira, hogy viszonyulása ambivalenssé, akár negatív előjelűvé is változhat, ami a munkaadó-alkalmazott közötti viszonyt igencsak bonyolulttá teszi, és kihatással lehet az érintett családi vagy egyéb kapcsolataira is.

Egy idegen háztartás vezetése, rendjéhez való igazodás, egy eladdig ismeretlen család ügyeibe való beavatottság, a gondozásra bízott személyekhez (gyermekek, idős, beteg emberek) való megfelelő viszony kialakítása, napi „menedzsmentje” nem kevés emocionális megterheléssel jár, ami pénzben aligha kifejezhető. Ráadásul nagyon gyakran itt egy sajátos feladatátadási láncolatról is szó van: a bevándorló/vendégmunkásnő munkájával mentesíti ugyan a nyugati középosztálybeli társát a háztartás, gyermeknevelés, esetleg az öreg vagy beteg szülőkre való felügyelés ügyes-bajos dolgaitól, lehetővé téve számára, hogy „éppoly esélyekkel jelenjen meg a munkaerő-piacon, mint a férfiak” ${ }^{15}$, ám ugyanezeket a feladatokat otthon, helyette mások látják el. S ha ez utóbbinak pénzben megállapított ellenértékét haza is vitte/ utalta (ami bár jóval kevesebb, mint amit ő ugyanezért vagy hasonló munkáért külföldön keres), ez nem jelenti azt, hogy az otthon maradt gyermekekkel, idős szülőkkel, családtagokkal való törődés „szünetelne”, vagy ez a kétirányú érzelmi-emocionális megterhelés ezzel a jövedelemkülönbözettel kiváltható volna.

A globális gondoskodási láncolat fogalmát Hochschild vezette be a szakirodalomba Parreñas tárgykörben megjelent munkájára utalva, abban az értelemben, hogy az itthon maradt nagyobb leánytestvér gondoskodik a kisebbekről, miközben az anya olyan gyermekekre felügyel,

13 Uo. 19-20.

14 Arlie Hoch schild: Global Care Chains and Emotional Surplus Value = On the Edge: Living with Global Capitalism. Eds. Will Hutton-Anthony Giddens. Jonathan Cape, London, 2000.

15 Anderson: i.m. 190; idézi Bartha: i. m. 80. 
akinek az édesanyja külföldön dolgozik, tehát maga is gyermekekre vigyáz, csak éppen valamelyik nyugati gazdag család gyermekeire. ${ }^{16}$ A 21 . század első évtizedeiben az idősgondozás tömeges elterjedése hasonló - nyilván a maga sajátos jegyeit magán viselő - jellegzetes láncolatokat eredményez, vagy éppen különféle párhuzamosságokkal a már létezőket még bonyolultabbá teszi.

Mindazáltal a szóban forgó nemzetközi gondoskodáskiszervezési láncolatnak - beleértve tehát a háztartási munkákat, a gyermekek felügyeletét, az öregek és betegek gondozását is van néhány lényeges jegye.

Először is, hogy reprodukál egy sor alapvető társadalmi (vagyoni, státusbéli és életstílusbeli stb.) egyenlőtlenséget mindenekelőtt a szegény és a gazdag országok/térségek között. ${ }^{17}$ Mahler és Pessar ezeket egyenesen a hatalom gender szempontú földrajzának - „Gendered Geographies of Power" - nevezi. ${ }^{18}$ Sajátos formája ugyanakkor a láncolaton végigkövethető nők és nők közötti egyenlötlenség, amelyből végeredményben adódik maga a jelenség: a háztartási és gondozó munkát végző nők nemzetközi migrációja. ${ }^{19}$

Másodsorban - miként a lánc metafora sejteti -, hogy kétirányú érzelmi-morális megterhelést jelent, kiemelten a láncolatok közepén lévő nőknek. S bár a háztartási és gondozói teendők elsősorban fizikai munkát jelentenek még a gépek mai fejlettségének a korában is, kétségkívül ennek a fajta munkának a fokozott pszichológiai megterhelés lényeges (esetenként a fizikainál jóval relevánsabb) összetevője.

A nemzetközi gondoskodási láncolat tehát igen sokrétű folyamat, amely - napjainkban az idősgondozás elterjedésével kibővülve - egyre inkább a globális munkaerő-vándorlás egyik fősodraként határozható meg, s mint ilyen, a gender szempontot napjaink migrációkutatásának egyik megkerülhetetlen tényezőjévé avanzsálja.

\section{ERDÉLYI NŐK, ASSZONYOK A GONDOSKODÁSI LÁNCOLATBAN}

A női migráció eltömegesedése bár világjelenség, ezt globális jellemzői ellenére sem lehet valamiféle homogén folyamatként beállítani. Szükséges figyelembe venni a különböző földrajzi-kulturális térségekben az egymástól eltérő társadalomtörténeti kontextusokat, nemkülönben a női társadalmak belső rétegzettségét, a női szerepekhez kapcsolódó hagyományokat, értékeket stb., azt a tágabb értelemben vett egzisztenciális helyzetet tehát, ahonnan egy fiatal lány, családanya, akár nagymama úgy dönt, hogy kimegy külföldre pénzt keresni. Az okok, motivációk, értelmezések, szereppróbák - variációk női vendégmunkára - az úgynevezett „szegény országok” között is nagyon eltérőek lehetnek.

16 Hochschild: $i . m$.

17 Nicola YeAtes: Global Care Chains: a Critical Introduction. Global Commision on International Migration (GCIM), Geneva, Switzerland, 2005.

18 Sarah Mahler-Patricia Pessar: Gendered Geographies of Power: Analysing Gender Across Transnational Space. Identities: Global Studies in Culture and Power 7(2001). 4. sz. 441- 459.

19 Rhacel S. Parreñas: Analytical Framework for Understanding Women's Migration. https://www. unitar.org/ny/sites/unitar.org.ny/files/Analytical\%20Framework\%20for\%20Studying\%20 Women\%E2\%80\%99s\%20Migration.pdf (2009) (letöltés dátuma: 2014. január). 
Tolstokorova közelítésmódja erdélyi nézőpontból kiindulópontként szolgálhat, tekintve, hogy a téma kapcsán a posztszocialista társadalmak sajátosságaira, illetve ezeken belül a térségben élö nók helyzetére irányítja a figyelmet.

Annak, hogy az erdélyi nôk tömegével vállalnak háztartási és gondozói munkát külföldön, nyilván megvannak az effajta munkákra vonatkozó, külföldi kereslettel összefüggő okai, az érem másik oldala viszont a kelet-európai, posztszocialista gazdasági-társadalmi kontextus, amely számos ponton különbözik a harmadik világból, illetve a nyugati országok volt gyarmatairól érkező nők (elindulási) helyzetétôl. Ezért szükséges ezért pár szóban kitérni a nők helyzetére a szocialista Romániában, amely kutatók szerint mélyen ellentmondásos volt. ${ }^{20}$

Tény, hogy a szocialista egyenlősítési törekvések folyományaként ebben az időszakban általánossá vált a nők munkavállalása (1990-ben az iparban alkalmazottak 42\%-a, a mezőgazdaságban pedig 56,4\%-a volt nő). ${ }^{21}$ Azonban a „munka mezején” megvalósított egyenlőséget nem kísérte olyan, a meghirdetett ideológiával koherens nő-, illetve családpolitika, amely ezt társadalmilag beágyazta, illetve konszolidálta volna, így ennek hiányában a „dolgozó nô” státusa mellett továbbra is meghatározóak maradtak a tradicionális női szerepek. ${ }^{22}$

A szocializmusból örökölt ambivalenciák a rendszerváltozást követően - például a a nők külföldi munkavállalásának sajátosságaiban - mutatkoznak meg igazi élességükben: nők tömegei kerültek ki a munka világából (vagy be sem kerülhettek), maradtak szociális biztonság (kereset, nyugdiji) nélkül, illetve kényszerültek vissza kizárólag a tradicionális női feladatokhoz (háztartás, gyermeknevelés, mezőgazdasági munka). Ha abból indulunk ki, hogy a szocializmusban megszokott volt, hogy a nőknek van, vagy (ha akarnak munkát vállalni) lehet fizetett munkahelye, a körükben elóállt tömeges munkanélküliség - „a szocializmus vívmányaihoz képest"- akár visszalépésként is értékelhető.

Kétségtelen, hogy a rendszerváltozást követően a romániai nők helyzete nagymértékben elbizonytalanodott (bár a rendszerváltozás gender aspektusairól igencsak keveset hallani!), a családfenntartásnak a szocializmus hosszú évtizedei alatt kialakult rendje alapjaiban ingott meg, megváltozott az egészségügyi ellátás, az addig „biztonságot ígérő” nyugdíjrendszer, a megörökölt hiánygazdaságban pedig rekordidő alatt terjedtek el a fogyasztói értékek. Mindez a családok, különösen pedig a családos vagy gyermeke(i)ket egyedül nevelố nôk terheit jelentős mértékben megnövelte.

Szemléletes e tekintetben E. esete, aki az egyik erdélyi faluból 18 éve jár külföldre takarítani. A szocializmusban csak a férjének volt munkahelye, egy keresetbőll három gyermeket neveltek fel („persze másak voltak az igények”). A változások után a férje megbetegedett, majd a munkahelye is megszúnt, kevés ideig Magyarországra járt ki dolgozni, alkalmi munkákra. Férjének betegsége azonban néhány év alatt elhatalmasodott, és 1995-ben meghalt. E. 43

20 NemÉnyi Mária: Testükbe zárva (A nôi szerep konstrukciója - elméletek és kutatások) = Szociológia emberközelben. Losonczi Ágnes köszöntése. Szerk. HanÁx Katalin-Nemény Mária. Új Mandátum, Bp., 1998; Geambașu Réka: Társadalmi nem és posztszocialista társadalmi változások. Erdélyi Társadalom II(2004). 1 sz. 167 (a továbbiakban Geambașu: Társadalmi nem); Uő: Patriarchátus a háztartás falain belül és kívül. Nemi egyenlötlenségek az erdélyi munkaeröpiacon. Erdélyi Társadalom VI(2008). 1-2 sz.117-148 (a továbbiakban Geambașu: Patriarchátus).

21 Geambașu: Patriarchátus 119-120.

22 Geambașu: Társadalmi nem 167. 
évesen maradt özvegyen, azóta külföldre jár takarítani, egyrészt, hogy magát eltartsa és összegyüjtsön valamit öregségére vagy betegség esetére (özvegységi nyugdíjra csak pár éve jogosult), másrészt pedig, hogy segítsen az otthon maradt hozzátartozókon. Gyermekei befejezték ugyan az iskolát, de nincs stabil állásuk (időszakos munkákból élnek, néha kijárnak ők is külföldre, ha adódik valami). Az időközben megnövekedett családban (van már több unokája is) gyakorlatilag ő az egyetlen stabil kereső. 61 éves, már egyre fárasztóbb számára az utazás, a „kinti” munka, amit tetéz az itthoniak iránti aggodalom. „Sokszor érzem, hogy megbolondulok, állandóan azon jár az eszem, hogy otthon ezeknek nincsen se erre, se arra pénzük! Hazamegyek, beszerzek, fózök, csomagokat küldök a busztól, pénzt küldök, még sincs soha, csak az aggodalom,------------- hogy mi lesz ezekkel itthon, ha már nem fogom birni?’ (I.II.01)

Kutatásaink azt mutatják: nem ritka, hogy külföldön dolgozó idősebb (akár nyugdíjas korú) nők tartanak el, vagy hathatósan támogatnak anyagilag egész családokat, a történet által szemléltetett módon: „ott dolgozok, de mielőtt még elmennék, itthon is beszerzek, pénzt és csomagokat küldök a menetrend szerinti járattal stb.”

Az erdélyi nők tömeges külföldi munkavállalásnak fő okai kétségkívül a gazdasági szerkezetváltás előidézte sokrétű bizonytalanságokhoz köthetők, de legalább ilyen fontos tényező, hogy ezzel a szerkezetváltással együtt járt a nyugati, ún. jóléti életmód és életstílus modellértéküségének általános elterjedése. Jellemző e tekintetben az olyan helyzet, hogy a vendégmunkásnőnek, esetleg felnőtt családtagjainak is volt/van itthon munkahelye, de alacsony a jövedelme, ám időközben olyan családi projektek zajlanak, amelyhez, az itthon megkereshetőnél nagyságrendekkel nagyobb jövedelem szükséges. Számos középkorú vagy nyugdíjas nő azért vállal háztartási és/vagy idősgondozói munkát külföldön, hogy segíteni tudja a felvett hitelek törlesztését, nagyobb családi beruházások megvalósítását (házépítés, nagyobb ingatlanfelújítások, vállalkozás indítása stb.) az itthon élő felnőtt gyermekei (és azok családjai) számára.

Másik vonzata a nők külföldi munkavállalásának a szocializmusban meghonosodott dolgozó nő státusának, valamint a kétkeresős családmodellnek az általános elfogadottsága. Azt tapasztaljuk ugyanis, hogy azok a nők, akiknek volt itthon munkahelyük - nyilván ezek képezik a külföldön szerencsét próbáló/elindulásra vállalkozó nők túlnyomó többségét -, nem szívesen térnek vissza kizárólag a tradicionális női szerepkörhöz, még idősebb korban sem, az otthoni háztartási munka nem kielégítő számukra, nehezen tudják elképzelni, hogy ne legyen önálló jövedelmük, és csak otthon a háztartásban vagy esetleg a mezőgazdaságban dolgozzanak. Úgy vélik: sokkal hasznosabb, ha külföldön pénzt keresnek, ha már adódik erre lehetőségük, mintha az idejüket itthon eltöltik, így érdemben hozzájárulhatnak a szűkebb-tágabb család jobb, nyugati színvonalat közelítő megélhetéséhez.

Az alacsony jövedelemmel járó és alacsony presztizsú nói állások jelentik a másik olyan motivációs tényezőt, amely az erdélyi nőket a külföldi munkavállalás irányába „mozgósítja”. Ők inkább fiatalabb és/vagy képezettebb nők, akik nehezen tudnak itthon elképzeléseiknek megfelelően elhelyezkedni. Ha adódna is valamilyen állás itthon, a jelenlegi migrációs korhangulatban - „mit akarsz itthon kezdeni?” stb. - ez kevésbé tűnik vonzónak, mint egy jó keresettel biztató külföldi (akár gondozói) munkalehetőség. Ezekben a döntésekben azonban a kényszerűség mellett általában a külföldi munkavállalás egyéb ígéretei (utazás, nyelvtanulás stb.), is belejátszanak. Itt említjük meg a pályaelhagyó nók csoportját is (például a pedagógusokét), akik egyre csalódottabbak a pálya presztízsvesztése, alulfizetettsége, bizonytalanságai miatt, „váltani” akarnak, a kilépéshez pedig kézenfekvő az ilyen jellegü külföldi munkavállalás. 
A mintába bekerült háztartási és gondozói munkát végző nők tehát életkor, családi helyzet, valamint iskolai végzettség szerint is igen heterogén csoportot alkotnak. Ezzel függ össze, hogy nézőpontjukból az effajta munkák megítélése eltérő. Vannak, akik letűnt időket idéző cselédsornak érzik, nem felel meg sem iskolai végzettségüknek, sem elvárásaiknak - kicsit szégyellik is erről beszélni; mások bár pragmatikusabbak - „ez is egy kereseti lehetőség”, „semmilyen munka nem szégyen” - de a szemérmesség általában erre a beállításra is jellemző.

A szóban forgó munkák személyes olvasata nyilván összefügg azzal is, hogy azt a családot, amelynek ügyes-bajos dolgaiba, gyerekeik, idős hozzátartozóik gondozásába az érintett nők besegítenek, befogadónak vagy inkább távolságtartónak érzékelik, illetve ők maguk milyen fokig várják el tôlük a befogadást, az érzelmi-morális odaadás viszonzását. Ezek rendkívül érzékeny határok vannak az emberi viszonyok kezelésében: „Azoknak nehezebb, akik nem tudják, hogy hol a helyük. Mert ezt azért tudni kell, meg kell érezni, ki kell tapasztalni, kifigyelni. Mondjuk, persze, ha neked rosszak a napok, megalázó, nem biztos, hogy hamar jobb helyet találsz. Nem könnyü, na...” (I.II.01)

Mindezzel együtt az érintett nők az interjúk során a történeteikbe nagyon kevés olyan konkrét panaszt, ${ }^{23}$ szőnek, amely a befogadó család tagjaira, úgymond a „munkaadóra” vonatkozna. Jellemzően „szerencsés helyzetben vannak”, akikkel a külföldi család, az ottani hozzátartozók, ha nem is túlságosan kedvesek, de mindenképpen korrektek, adódnak ugyan problémák, de azt sikerül mindig valahogy a helyükre tenni. Ez nyilván lehet elhallgatás, a negatív élmények elmesélését szégyenérzet, szemérmesség, akár maga az interjús (kvázinyilvános) helyzet is gátolhatja, ám úgy tünik, hogy az esetleges sértéseket, megalázásokat inkább ezekkel a munkákkal együtt járó természetes jelenségeknek tudják be.

Ami kritikaként mégis megfogalmazásra kerül, az általánosabb szintű: a nyugati típusú atomizált családmodellt érinti.

„Én Németországban egy nagyon idős nénit gondozok, aki le van bénulva, teljes ellátásra szorul. Etetem, pelenkázom, minden. A fiával tartom a kapcsolatot, aki jön hetente és pénzt hagy bevásárlásra, vagy felhívhatom, ha baj van. ---------- De a fia sokszor eljön, leteszi a pénzt, be se néz az anyjához! Úgy viselkedik, mint egy idegennel. [...] Azt mondta volt, mikor megjöttem, az anyja nem ért semmit, nem hall, nem fog fel semmit abból, ami körülötte történik. Pedig én, ha kérdezem, hogy jó volt-e az étel, előfordul, hogy int, vagy mosolyog." (II. I.05)

„Ott a családnak nincs olyan szerepe, mit itthon. Nem ilyen családcentrikus emberekkel találkoztam, ott inkább mindenki a pénzre, a munkára hajtanak, keveset foglalkoznak az idősekkel, a gyerekekkel. Éppen ezért van szükségük külföldiekre, akik vigyázunk az ők gyerekeire és öregjeire.”(I.20)

23 Ezek olyan történetek, amelyek az irántuk való bizalmatlansággal függnek össze, pl. ,azt hitték az elején, hogy olyan buta vagyok, hogy nem tudok felhúzni egy ágynemüt, nem láttam életemben tisztítószert, háztartási gépeket, hát jött a sógornó, hogy megmutassa, ez nekem nagyon rosszul esett" (II.I.09). 
Nyíltabban beszélnek viszont, arról a fokozott pszichológiai-morális megterhelésről, amellyel ezek a munkák együtt járnak, kiemelt tekintettel az idősgondozásra. Említettük az előzőekben, hogy az idősgondozás tömeges kiszerelése a külföldi munkavállalóknak egy viszonylag új fejezetét nyitotta meg a női vendégmunkának, mintánkban is az idősgondozással foglalkozó nők vannak többségben. Ez minden bizonnyal nem csupán erdélyi sajátosság, s előrevetíti, hogy a női munka nemzetközi keresletét illetően - legalábbis Kelet-Európából - a gyermekgondozásról egyre inkább átkerül a hangsúly az idősgondozásra.

A munka sajátos jellegét illetően érdemes kiemelni pár olyan aspektust, ami az idősgondozó nők emocionális megterhelését - a többi háztartási/gondozói munkához képest is - felerősíti. Egyik a bentlakó életmód, az idegen, zárt terekben ${ }^{24}$ a munka, illetve az idő folyásának egyhangúsága, monotonitása. „Borzasztóan magányos voltam, ----------- volt, hogy a néni felkelt 6-kor, de volt, amikor csak 11-kor, elláttam, ahogy kellett, de azután----- egyszerüen nem volt, mivel eltöltsem az időmet!!! Sokáig, mondjuk, magára se lehetett hagyni, --- nem volt, akivel beszélgessek, irtózatosan lassan telt az idő. Szörnyú unalmas volt!!!” (II.I.05) Másik a fokozott türelmesség és morális állóképesség, amit ez a fajta munka megkövetel:, A gyerekre rászólsz, ha valamit csintalankodik, az meg elkezd sirni, visit, vagy visszamosolyog, vagy valami..........szóval élet van a dologban. ------------------------ Egy idós emberre nem szólhatsz rá, fóleg ha beteg, vagy magatehetetlen, kiszolgáltatott, neki mindent el kell türjél. ------ ez nagyon-nagyon nebéz, ------ mert végül is mi van? ----- Ez a néni például 89 éves, szerintem nem is kelne fel már, ha én nem mennék be hozzá reggelente, és nem ébresztgetném." (I.II.03)

Az idősgondozás nemzetközi kiszerelésének kapcsán sajátos jelenség az erdélyiség exportja az emigrációba. Számos erdélyi nő ugyanis olyan időseket gondoz külföldön, akik innen mentek el valamikor vagy utólag vitték ki őket a kitelepült gyermekek (erdélyi magyarok, szászok, svábok, zsidók). Ezeknek az időseknek otthonos az erdélyiség, általában ismerik - és szívesen beszélik - a magyar és a román nyelvet egyaránt, amire gyakran csak a gondozónővel nyílik alkalom. Így a vendégmunkás erdélyi nők munkaerejük mellett az erdélyiséget is (vissza)viszik a kitelepült időseknek, ami külön apport, és növeli az irántuk való keresletet. Nyilván a kint dolgozó erdélyi nőknek is előnyös ez a helyzet, ám lényeges, hogy ebben a típusú gondoskodási láncolatban fontos szerepet játszik maga az erdélyi kultúra is.

„Kérdés: $\mathrm{S}$ a német nyelvet jól tudtad?

Válasz: Szerencsém volt, mert a néni Erdélyből kivándorolt szász volt, aki tud románul és tud magyarul, én pedig mellette megtanultam egy kicsit németül.”(I.II.04)

„Kérdés: Jól hallom, hogy ott a háttérben a Duna TV megy?

Válasz: Hát persze, egész nap! Egész nap a Duna World! Azért sok a román szó is, vannak román anyanyelvű rokonok, de ezek mind otthonról, Erdélyből települtek ki. Hébert én csak bevásárláskor használok, van ilyen kis szótáram, füzetecském! De sok itt az erdélyi asszony, egymás-

24 Figyelemre méltó, ahogyan az idegen házakat leírják a bentlakó idősgondozónők: „nagy barna ajtók", "magas barátságtalan szobák", ,valami hatalmas kastélyként képzeld el, mint a filmekben, abol él egy öregasszony" stb.). 
sal is tartjuk a kapcsolatot a Facebookon, Skype-on, sokféle módon, sőt a moldáviaiakkal is." (I.II.03)

Sajátosak továbbá a női hálózatok, amelyek végeredményben ezt a fajta munkaerő-vándorlást müködtetik. Noha szép számmal léteznek közvetítő ügynökségek (hivatalosan, félhivatalosan és feketén egyaránt), kutatásunk alapján az látszik, hogy ezek a munkalehetőségek nagyobbrészt mégis informális szálakon bonyolódnak, s ebben jelentős az erdélyi (e)migráció jellegzetes női hálózatainak a szerepe: „a menyem kint orvosnő, akinek a fodrásznóje mondta, hogy azó barátnóje keres valakit, aki besegitene” stb. (I.II.04)

A női migrációs hálózatok élő kapcsolatokat, és ennél fogva bizonyos mértékű védelmet is jelentenek az érintett nők számára, abból adódóan, hogy túlmutatnak munkalehetőségek puszta közvetítésén. A csoportok tagjai ugyanis tartják egymással a kapcsolatot, kint is, és itthon is összejárnak, elég gyakori, hogy saját Facebook-oldalt, levelezőlistát stb. is működtetnek. Ez a személyes és virtuális hálózatosság segít az idegenség elviselésében, lévén közösek a témák, a felmerülő ügyes-bajos dolgok megbeszélve/kibeszélve általánosabb szintre kerülnek, medret kínálva a különféle problémák bizonyos mértékü feldolgozására. De ilyen társas/társalgási keretet jelentenek az oda-vissza való közös utazások is, amelyek egyúttal alkalmak arra, hogy a szelepek kinyíljanak, segítsék a megérkezést haza vagy éppen a másik otthonba.

\section{„HOGY LEGYEK »BELLA, BELLA...«”- NÖI SZEREPÉRTELMEZÉSEK, A VÁNDORLÁST KÍSÉRŐ SZEREPKONFLIKTUSOK}

Fontos vonzata az erdélyi nők külföldi munkavállalásának - amely talán egyik nem szándékolt következménye is - a női szerepértelmezésekkel, illetve ezek változásaival függ össze. A nyugati tapasztalatok fényében a hagyományos női szerepkörök is más megvilágításba kerülnek, s az ottani életstílussal, mentalitással összefüggő benyomások, élmények pedig értelemszerűen másfajta női önértékeléssel, illetve másfajta időkezeléssel (munkaidő-szabadidő) szembesítik az erdélyi nőket. Ezeket a különbözőségeket jól tolmácsolják az alábbi interjúrészletek:

„Az ottani mentalitáshoz talán az tartozik [s ami itthon nem szokás] (közönyösen, kicsit gúnyosan meséli), hogy minden este vacsora után ki szoktak menni a városba egy üdítőt vagy egy italt meginni. És itt ..........., ami eszembe jut ez, és minden este elhangzott, hogy: megyünk valahova ma este, vagy megyünk inni valamit, vagy megyünk sétálni? Ez ilyen természetesnek talált mondás, elszólás, mert ők minden este kimennek, ez náluk már egy ilyen rutinszerűvé vált ez a mondás...”(I.20)

„Persze, a mentalitás is, az is, az is [más], tudja meg! Hát egyszer én mondtam, hogy idős vagyok [47 éves] és a néni, hát 77 éves volt, jaj, hogy megszidott engem! Hát a bábuska 77 évesen is festette a haját, sminkelte magát, folyton fésülködött, és engem is odatett, hogy legyek „bella, bella”! (Nevetnek.) Mondtam én, hogy nem akarom, de ők nagyon respektálják magukat, ha van valami a kisujjukkal, azonnal rohannak az orvoshoz, jaj, 
Uram, istenem, ilyent életemben nem láttam. [...] Hát nem értett románul, én neki mondtam, hogy „baba”, nem tudta mi az, én meg mondtam, hogy azt jelenti, hogy „bella”, egyszer valamiért kiszaladt a számon, hogy vénaszszony, jaj, hogy megharagudott, azt mondta ,giovanile”, jaj! [...] Ott az asszonyoknak nagyon fontos, hogy értékeld magad, elegáns és szép legyél, hát mondom: ez 77 éves volt, s a szomszédja [hasonló], hát [átjött] hozzá magas sarkú szandálban! (I.14)

Ezekből a szembesülésekből, szerepkonfliktusokból adódik, hogy a kérdéssel összefüggésben az erdélyi nők elbeszélései egy sor ambivalenciát tükröznek:

- noha vonzóbbnak, szabadabbnak tủnik fel a nők helyzete/szerepe külföldön - mint a társuló intonációk és a modalitás is tanúsítja -, az erdélyi nôk a történet-mesélések során mégis inkább konzervatívabbnak, a tradicionális női szerepekhez igazodónak mutatkoznak;

- bár a külföldi munkavállalás fô pozitívuma az itthon elérhetőnél nagyságrendekkel jobb pénzkereset, mégis társul az elbeszélésekhez bizonyos mértékủ szemérmesség, szégyenérzet, elhallgatás;

- bár érdemben - kívülről nézve - a pénzkereset a fő megvalósítás, a nők önértékelésében mégis másfajta személyes teljesítmény túnik meghatározónak: „el mertem indulni”, „meg tudtam csinálni”, „elboldogultam egy idegen világban, egy idegen házban, egy idegen nyelven”, megtanultam a számítógépet használni stb.

Mindent egybevetve: bár az indulási motiváció a pénzkereset, esetleg az itthoni szegénység enyhítése, elmondható, hogy erre a vándorlások során másfajta személyes igények, értékválasztások is ráépülnek, úgy is fogalmazhatunk, hogy az erdélyi nőket az itthoni tradicionális szerepeknél mozgalmasabb, ingergazdagabb életre állítja be a külföldi munkavállalás. Ebből adódik, hogy hosszabb vendégmunka-időszak után, a hazatérést követően, a hagyományos női szerepkörhöz kapcsolódó elvárások újabb kihívás/sorsértelmezés elé állítják a visszatérő nőket.

A hagyományos női szerepértelmezés szerint - amely még mindig meghatározó Erdélyben - egy nőnek mindig akad munkája a háztartásban, a ház körül, „amit nem lehet befejezni, csak abbahagyni”. A tradicionális női idôkezelés tehát egy olyan kontinuummal számol, amelyben hagyomány, neveltetés kérdése, hogy mi is és mennyi is a szabadidô, illetve hogyan strukturáljuk az idôt. Az oda-vissza való vándorlások folyamán azonban az idô szakaszolása egyre inkább igénnyé válik, az érintett nők gyakran említik, hogy külföldön a munka, minden nehézsége ellenére azért is kevésbé stresszes, mint az itthoni, mert „kint”van megszakítottság, van szabadidő, szabadnapok, lehetőség van lazítani, egyébbel foglalkozni, utazni. Ez az évek során megszokottá válik, miként az is, hogy az itthoni tartózkodás után másik időszak következik: másfajta ház, másfajta feladatok, másfajta gondok. „Nem lenne jobb csak itthon. Megmondom miért. Összefolyik minden itthon, nem találom a helyemet. Nem tudom, mit is csináljak, voltam igy, de nem volt jó. Így tudom, ott mi a dolgom, ha hazajövök, ennyi idó alatt mit tudok megcsinálni. Most itthon vagyok már egy hónapja, kicsit rossz érzés, hogy megint kell menni, de még rosszabb lenne ejsze, ha nem kéne. Nem is tudom... (zavart nevetés)"(I.II.01)

Végezetül szükséges pár szót szólni - a vázolt ambivalenciákkal összefüggésben - a vendégmunkás nők itthoni alkupozícióiról. A nemzetközi vizsgálatok, illetve saját kutatásaink is azt mutatják, hogy a nők külföldi munkavállalása - és hathatós anyagi támogatása a család- 
fenntartáshoz - nem jár együtt azzal, hogy az itthon maradt férfiak nagyobb részt vállalnának ezekből a fajta munkákból. Ahogyan a tanulmány elején E. példáján szemléltetett kétirányú gondoskodási módozat tanúsítja, ezek a fajta munkák túlnyomórészt továbbra is nők és nők között oszlanak meg, lévén par excellence nói feladatok. Következik, hogy a nők alkupozícióit, akár a vendégmunka időszakában, akár a hazatérést követően, nagymértékben lehatárolják az itthon érvényes társadalmi normák és az ezekre épülő elvárások.

Számba véve ugyanakkor a női vendégmunka gazdasági vonzatait, ennek anyagi haszna valóban figyelemre méltó mindkét fél számára. A külföldi munkaadónak a háztartással együtt járó feladatok (takarítás, mosás, vasalás, bevásárlás stb.) így nagyon olcsón megoldhatók: idejét, energiáit másfajta tevékenységekre fordíthatja. A gondozói vendégmunka talán még ennél is kifizetődőbb, hiszen egy külföldi gondozót alkalmazni jóval olcsóbb, mintha egy ottanit, vagy egy idősotthon havi költségekeit fedezni, ráadásul ezzel a „megoldással” az idős szülők, hozzátartozók ingó-ingatlan vagyona is megmarad az örökösöknek. A vendégmunkásnőknek ugyanakkor nagy előny, hogy különösebb előképzettség vagy nyelvismereti szint nélkül elvégezhető munkákról van szó, ami relatíve jó kereseti lehetőség, hiszen nagyságrendekkel haladja meg azt a jövedelemszintet, amelyet a nők többsége Romániában valaha elérhet.

Ha azonban a teljes folyamatot nézzük, akkor nyilván a női munkaerő-vándorlás árnyoldalait is világosan láthatjuk: a fizikai, lelki-morális igénybevétel következményeit, az idővel jelentkező, gyakoribbá váló egészségügyi gondokat, az elhasználódást, az itthoni világtól, közösségtől való bizonyos mértékű elidegenedést, amely hosszasabb vendégmunka-időszak után az érintett nők esetében óhatatlanul bekövetkezik.

\section{POSZTMODERN CSELÉDSORS? ZÁRÓ GONDOLATOK}

A fentebb bemutatott folyamat posztmodern? Abban az értelemben mindenképpen, hogy a női munkavállalás - a külföldön elvégzett háztartási és gondozói munka elterjedtsége folytán - a nemi szerepeket, illetve a társadalomszerkezeti határokat feszegeti. Jellemzően női munka, de valójában „kenyérkeresés”, jelentős jövedelem, esetenként pedig családfenntartás. Ilyen értelemben egyfajta „férfiasodás”.

A munkavállalási életkor kitolódása pedig az aktív és az inaktív lakosság közötti választóvonalat relativizálja, bizonyos pontokon felülírva az európai társadalomtörténet évszázados sémáit, hiszen ki gondolta volna akár pár évtizeddel ezelőtt is, hogy nyugdíjas nők, akár nagymamák veszik nyakukba a világot, nyelveket tanulnak, hogy eltartsák, vagy külföldi munkavállalással anyagilag segítsék fiaikat, unokáikat?

Sőt, az a jellegzetesség is, hogy az erdélyiségre igény van Nyugaton, s a vendégmunkás gondozónők révén ez visszatalál az emigráció idós korosztályához, a modernizációs korokhoz képest igen figyelemreméltó aspektus, ha azt vesszük, hogy valamikor külföldi (német, francia, angol) nevelőnők voltak szegődtetve tehetősebb erdélyi családok gyermekeit pallérozni...

Cselédsors? Ha azt nézzük, hogy a gazdagabb, jómódú mások kiszolgálásáról, ellátásról van szó, akkor kétségtelenül a háztartási és a gondozói munka nem egy előkelő munkaerőpiaci helyzet. Ráadásul, lévén jobbára egy informális alkalmazási gyakorlat szerint múködik, az 
érintett nők bizonytalansága, esetleg kiszolgáltatottsága sajátos lelki teher és kockázati tényezô.

Ha azt nézzük viszont, hogy jóval nagyobb jövedelmet jelent, mint amit az itthoni munkaerőpiacon a nők többsége elérhet, akkor értelmezés kérdése, hogy magát a munkát miként állítjuk be. Arról nem is beszélve, hogy ez attól is függ, hogy ezt a gondoskodási láncolat melyik oldalról nézzük? Egy külföldön dolgozó takarítónő vagy idősgondozó lehet itthon akár munkaadó, akire az, aki tőle az itthoniak gondozását átvállalja, felnéz, akitől az ő egzisztenciája függ, mert ez utóbbinak esetleg nincs lehetősége kimenni, vagy nincs hozzá bátorsága, vagy nem tud nyelveket stb. Így ô is valójában abból él, hogy a másik kimegy külföldre pénzt keresni.

Ami nem relatív viszont, az a másokról/másikról való gondoskodás természete, amely minden korban az emberi társadalom reprodukciójának alapfeltétele, és fizikailag, emocionálisan és morálisan egyaránt igénybe veszi a gondoskodót.

\section{MÓDSZERTANI MELLÉKLET}

A beszélgetések (31) a Migráció és gazdasági kultúra c. kutatáshoz 2011 decembere és 2012 márciusa között készültek Erdélyben, olyan személyekkel (magyarokkal és románokkal vegyesen), akik (a.) hosszabb ideig kijártak dolgozni valamelyik nyugati országba, (b.) életvitelszerűen éltek külföldön, vagy akár ki is települtek, de végül a hazatérés mellett döntöttek. A mintát hólabdamódszerrel választottuk; 11 nő került a mintába, ebből 8 háztartási vagy gondozói munkát (is) végzett külföldön (átlagéletkor 36,1 év).

A Posztmodern cselédsors? Háztartási és gondozói munkát végzó erdélyi nók külföldön c. kutatás az előző vizsgálat folytatásaként 2014. január-február időszakban készült, ugyancsak interjús módszerrel, illetve be nem avatkozó megfigyeléssel. 9 nővel készült beszélgetés, mindannyian magyar nemzetiségűek, akik háztartási és gondozói munkát végeznek, vagy végeztek külföldön az elmúlt években (átlagéletkor 48,6 év).

A két minta alapváltozók szerinti megoszlását az alábbi táblázat tartalmazza.

1. táblázat. Interjúalanyok

\begin{tabular}{|c|l|c|l|l|}
\hline $\begin{array}{c}\text { Az interjúk } \\
\text { kódja }\end{array}$ & $\begin{array}{c}\text { Az eredeti } \\
\text { foglalkozás }\end{array}$ & Életkor & $\begin{array}{c}\text { A külföldi munka } \\
\text { jellege }\end{array}$ & Ország \\
\hline \multicolumn{5}{|c|}{$2011-2012-$-es kutatás } \\
\hline I.09 & színművész & 33 év & gyermekfelügyelet & Ausztria \\
\hline I.13 & tanár & 40 év & takarítás & Olaszország \\
\hline I.14 & ápolónő & 47 év & idősgondozás & Olaszország \\
\hline I.17 & - & 25 év & idősgondozás & Németország \\
\hline I.18 & közgazdász & 26 év & takarítás & Írország \\
\hline
\end{tabular}




\begin{tabular}{|c|c|c|c|c|}
\hline $\begin{array}{l}\text { Az interjúk } \\
\text { kódja }\end{array}$ & $\begin{array}{l}\text { Az eredeti } \\
\text { foglalkozás }\end{array}$ & Életkor & $\begin{array}{l}\text { A külföldi munka } \\
\text { jellege }\end{array}$ & Ország \\
\hline I.19 & - & 25 év & $\begin{array}{l}\text { takarítás, } \\
\text { egyéb házimunkák }\end{array}$ & Magyarország \\
\hline I.20 & tanár & 31 év & gyermekfelügyelet & Olaszország \\
\hline I. 21 & könyvtáros & 62 év & idősgondozás & Olaszország \\
\hline \multicolumn{5}{|c|}{ 2013-2014-es kutatás } \\
\hline II.I.01 & - & 61 év & takarítás & Magyarország \\
\hline II.I.02 & könyvelő & 29 év & takarítás & Magyarország \\
\hline II.I.03 & bolti eladó & 44 év & idősgondozás & Izrael \\
\hline II.I.04 & nyugdijas & 64 év & idősgondozás & Németország \\
\hline II.I.05 & könyvelő & 53 év & idősgondozás & Németország \\
\hline II.I.06 & nyugdíjas & 60 év & idősgondozás & Nagy-Britannia \\
\hline II.I.07 & tanár & 39 év & takarítás & Ausztria \\
\hline II.I.08 & nyugdíjas & 64 év & idősgondozás & Németország \\
\hline II.I.09 & érettségi & 24 év & gyermekfelügyelet & Nagy-Britannia \\
\hline
\end{tabular}

\section{POSTMODERN SERVANTS? \\ DOMESTIC WORKERS AND ELDERCARE WORKERS FROM TRANSYLVANIA IN WEST}

\section{Keywords: transnational migration of women, domestic work, care workers, structural changes}

Taking notice of the feminization of international migration, which has become obvious at the turn of the millennium, the paper discusses the issues of female foreign workers. Our starting point is that the tasks of Transylvanian women who decide to work abroad mostly consist of domestic works and elderly care, this study focuses on this type of work and the specific cultural exchange related to it. We present these feminine tasks in the frames of the notion global care chains (Hochschild 2000, Parrenas, 2001). Particular for the caring chains is, on one hand, that it reveals and also reproduces a whole series of social inequalities, on the other hand - as the metaphor of the chain plastically suggests - that it means a double-directional emotional and moral burden accompanying the work, which emphatically affects the women who are in the middle of such a chain. A typical phenomenon related to this topic is the export of Transylvanian specific into the emigration. This means that many Transylvanian women care abroad for elderly people - originating from Hungarian, Swabian, Saxonian or Jewish communities - who left Transylvania themselves or who have been taken to other countries by their children. These seniors feel like home thank to the Transylvanian specific provided by the female foreign workers, and for these women it is a significant advantage that they can use their mother tongue at work. Therefore, in this kind of caring chain the Transylvanian culture itself plays an important role. Regarding all the mentioned aspects, we can affirm that the particularities of female foreign work (the widespread task of elderly care, the extension of active working age, the presence of typically feminine networks within the system of migration etc.) place the changes of social structures in a new light, which can be defined by many aspects relevant for gender studies. 


\section{SERVITOARE POSTMODERNE? \\ FEMEI DIN TRANSILVANIA ÎN OCCIDENT}

\section{Cuvinte-cheie: migrația internațională a femeilor, munci domestice şi de îngrijire de vârstnici, schimbări de structură socială}

Având în vedere procesul de feminizare a migraţiei la începutul secolului 21. studiul tratează tematica migraţiei de muncă a femeilor transilvănene în Occident, bazându-se pe cercetări empirice calitative. Plecând de la faptul că femeile în cauză se ocupă preponderent de munci domestice sau sunt îngrijitoare de vârstnici, studiul se concentrează asupra particularităţilor acestor activităţi. Procesul preluării-predării acestor sarcini este prezentat cu ajutorul conceptul de înlănţuire internaţională a activităţilor de îngrijire (global care chains - Hochshild 2000, Parrenas 2001). Acest proces evidenţiază pe de o parte un şir de inegalităţi sociale, iar pe de altă parte - cum sugerează metafora de lanţ - este vorba de o solicitare fizică, emoţională şi morală dublă a femeilor migrante, mai cu seamă în cazul celor din mijlocul lanţului. Un alt fenomen specific legat de acest proces este „exportul Transilvaniei în emigraţie”. Este vorba de faptul că multe femei din Transilvania îngrijesc persoane în vârstă care au plecat definitiv din această regiune - maghiari, saşi, şvabi, evrei - sau au fost duşi ulterior din ţară de către copii emigraţi. Pentru aceşti bătrâni cultura transilvăneană este familiară, situaţie care la rândul ei prezintă avantaje şi pentru femeile în cauză. În consecinţă în mecanismul de funcţionarea a acestui tip de înlănţuire al activităţilor de îngrijire transnaţională joacă un rol important însăşi cultura transilvăneană. $\mathrm{Cu}$ toate acestea, particularităţile migraţiei de muncă a femeilor (caracterul răspândit a muncii de îngrijire de bătrâni, prelungirea vârstei medii a femeilor activi pe această piaţa internaţională a muncii, reţelele „feminine” între migranţi-emigranţi etc.) pun într-o perspectivă specifică - de gender studies schimbările sociale majore ale începutului de mileniu. 